\title{
Solar Energy: Materials, Devices, and Applications
}

\author{
Ru-Yuan Yang, ${ }^{1}$ Yu-Pei Huang, ${ }^{2}$ Nowshad Amin, ${ }^{3}$ and Fengqiang Sun ${ }^{4}$ \\ ${ }^{1}$ Graduate Institute of Materials Engineering, National Pingtung University of Science and Technology, Pingtung 91201, Taiwan \\ ${ }^{2}$ Department of Electronic Engineering, National Quemoy University, Kinmen 89250, Taiwan \\ ${ }^{3}$ Department of Electrical, Electronic, and Systems Engineering Mathematics, National University of Malaysia, 43600 Bangi, Selangor, \\ Malaysia \\ ${ }^{4}$ Department of Materials Science and Engineering, South China Normal University, Guangzhou, Guangdong 510631, China
}

Correspondence should be addressed to Ru-Yuan Yang, ryyang@mail.npust.edu.tw

Received 2 December 2012; Accepted 2 December 2012

Copyright (C) $2012 \mathrm{Ru}$-Yuan Yang et al. This is an open access article distributed under the Creative Commons Attribution License, which permits unrestricted use, distribution, and reproduction in any medium, provided the original work is properly cited.

As "a low-carbon society and $\mathrm{CO}_{2}$-free energy" have been the global issues, so have the opportunities and challenges for renewable energy technologies, like photovoltaic solar cells. Solar energy is an alternative of fossil fuels. Dyesensitized solar cells (DSSCs), organic thin-film solar cells, quantum dot solar cells, Schottky solar cells, inorganicorganic heterojunction solar cells, and many others have been developed with the promise of further improvements to both performance and affordability expected during the last years.

The aim of this special issue has been to present the latest and generalized coverage of the fundamental and constructive ideas, concepts, and important issues in the accepted original research articles stimulating the continuing efforts to solar energy. We received 12 research papers in the research fields. This special issue includes 8 high-quality peer-reviewed papers. We hope that this collection of papers will be a source of ideas and motivation for scientists across different fields in academia and industry to continue further research on solar energy including topics about materials, devices, and applications.

In the fascinating paper by A. M. Abdel-Ghany and I. M. Al-Helal, under solar radiation conditions, the modeling approach has been used to determine equivalent optical constants of plastic shading nets. W.-s. Kuo and C.-l. $\mathrm{Wu}$ provide a treatment of color filter wastewater using solar photo-Fenton process enhanced by high-concentrating Fresnel lens. Series resistance analysis is presented by M. Lenio et al. for passivated emitter rear contact cells patterned using inkjet printing. In the nonvacuum processes for solar cell materials, S. Ito and T. Ryo are working successfully on finding segregation of $\mathrm{Cu}-\mathrm{In}-\mathrm{S}$ elements in the spraypyrolysis-deposited layer of solar cells. In the interesting paper by $\mathrm{H}$. Zhao et al., the experimental study on solar cooling tube has been built using thermal/vacuum emptying method. These wonderful results in the studies of ruthenium complex sensitizer and gold nanoparticles doped flexible organic solar cells are given by L.-C. Chen and C.-C. Chen. Organic compounds effect on microstructure, optical, and electrical properties of ITO thin films prepared by dip coating method has been investigated by Y.-M. Peng et al. Finally, the other published paper has good studies on providing the phenomenon of performance degradation induced by electrolytes for dye-sensitized solar cells by H.-Y. Chen et al.

\section{Acknowledgments}

The Guest Editors are very thankful to the authors for their fascinating and interesting contributions to this issue with high-quality papers. We are particularly indebted to the staff of Advances in Materials Science and Engineering for their professional and timely support. Additionally, we would also like to show our greatest appreciation to the reviewers for their valuable suggestions/comments to make the special issue successful with highly qualified published papers.

\section{Ru-Yuan Yang Yu-Pei Huang Nowshad Amin Fengqiang Sun}



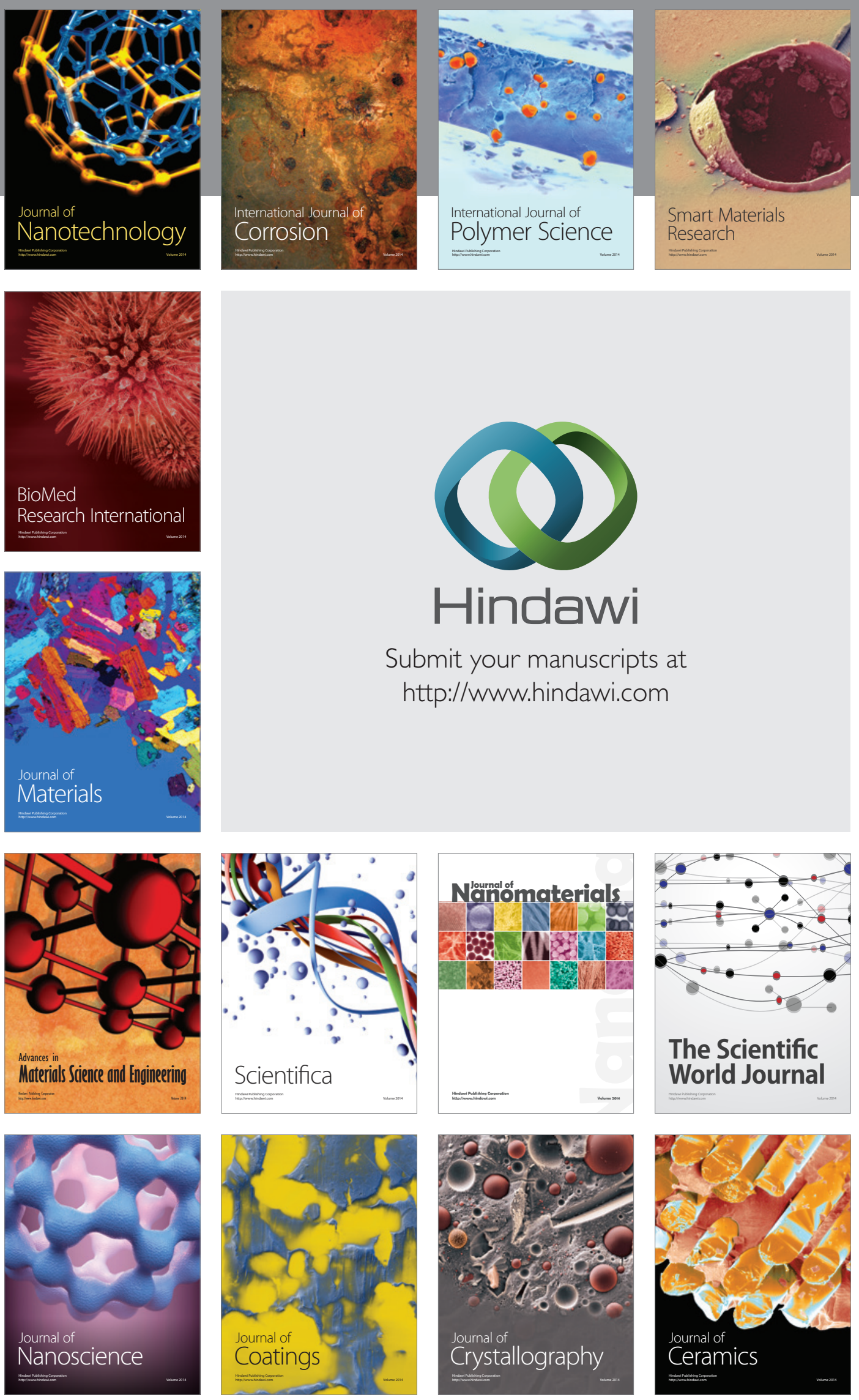

The Scientific World Journal

Submit your manuscripts at

http://www.hindawi.com

\section{World Journal}

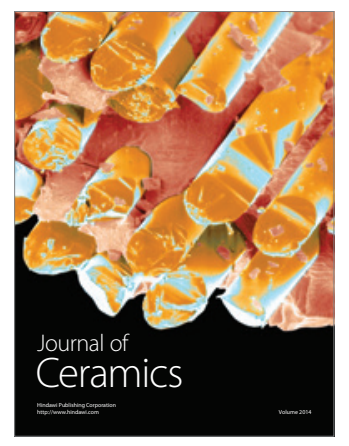

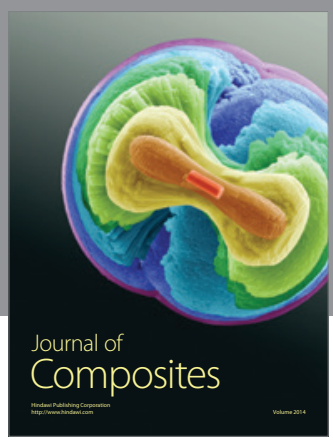
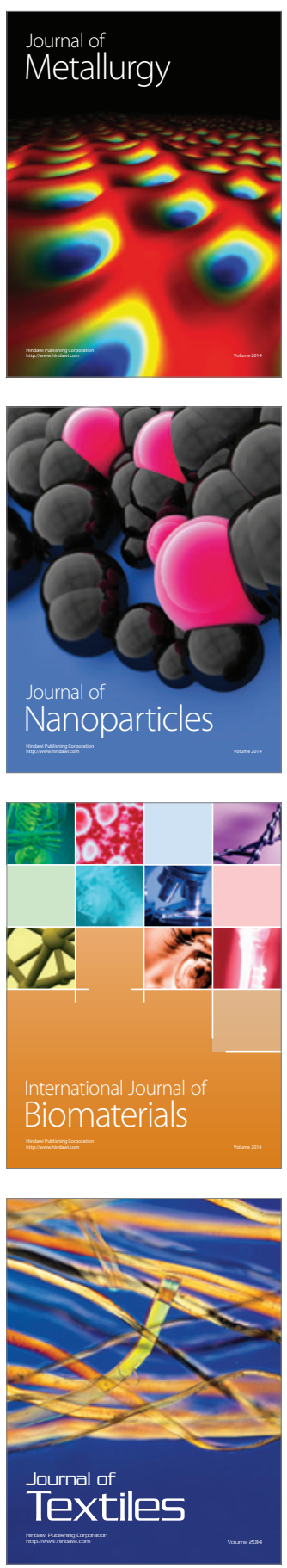